\title{
Tanggung Jawab Pelaku Usaha Pertambangan Rakyat dalam Reklamasi Gumuk Setelah Kegiatan Tambang
}

\author{
Ade Lutfi Prayogo \\ University of Jember, Indonesia \\ adelutfiprayoga@gmail.com
}

\begin{abstract}
The responsibility of mining businesses in carrying out post-mining reclamation activities applies to all mining business permits including holders of the People's Mining Permit (IPR). The arrangement of post-mining land reclamation activities for small-scale mining business people on what so-called 'gumuk' mining is still not efficient regarding its making and implementation. Legal responsibility for IPR holders in the preparation of plans, implementation, and sanctions provided still depends on regulations made by the regional government. The norm gap still exists if there is a lack of guarantee costs for post-mining reclamation due to the absence of mandatory guarantee funds. This is evidenced by the fact that there are still many regional governments that have not made regulations on reclamation and post-mining by IPR holders. Therefore, it is necessary to add norms to regulations that regulate reclamation and post-mining activities for community mining businesses. The addition of norms also needs to be done to the implementation rules so that environmental functions can be functioned properly by community mining business actors.
\end{abstract}

KEYWORDS: Responsibility, Business Actors, People's Mining.

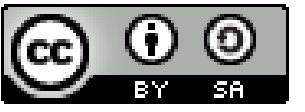

Copyright $\odot 2018$ by Author(s)

This work is licensed under a Creative Commons Attribution-ShareAlike 4.0 International License. All writings published in this journal are personal views of the authors and do not represent the views of this journal and the author's affiliated institutions.

\section{HOW TO CITE:}

Prayogo, Ade Lutfi. "Tanggung Jawab Pelaku Usaha Pertambangan Rakyat dalam Reklamasi Gumuk Setelah Kegiatan Tambang” (2018) 5:3 Lentera Hukum 449-462.

Submitted: July 26, 2018 Revised: October 22, 2018 Accepted: December 22, 2018 


\section{PENDAHULUAN}

Indonesia merupakan negara yang memiliki banyak gunung aktif sebagai penghasil panas bumi serta batuan yang membawa mineral, karena Indonsia terletak dalam wilayah strategis dalam segi geografis dan astronomis. Hal ini dikarenakan letak geografis Indonesia dilewati oleh jalur pegunungan dunia yaitu (sirklum mediterania dan sirklum pasifik), sedangkan dalam letak astronomisnya Indonesia pada jalur katulistiwa. Indonesia merupakan negara beriklim tropis yang memiliki banyak keanekaragaman flora dan fauna sejak berjuta tahun lalu, dari segi geografis dan astronomis menguntungkan Indonesia sebagai negara penghasil sumber daya mineral yang tersebar di seluruh wilayah Indonesia. Selain itu Suryadi menjelaskan bahwa Indonesia terletak pada posisi yang strategis, sehingga melahirkan struktur geologi dengan potensi pertambangan yang telah diakui di dunia. Indonesia memiliki keunggulan dalam produksi tembaga, emas, perak, nikel, dan batubara. ${ }^{1}$

Dengan kondisi geografis Indonesia yang memiliki banyak gunung aktif menjadikannya memiliki banyak gumuk dengan ketinggian berkisar antara 1 meter sampai dengan 57,5 meter. Gumuk di Indonesia memiliki kandungan bantuan yang berbeda beda, kebanyakan kandungan gumuk di Indonesia terdiri dari gumuk batu, gumuk batu piring dan gumuk pasir. Gumuk yang ada di Indonesia terbentuk dengan proses sangat lama sehingga merupakan kejadian alam yang langka dan tidak dapat diperbarui. $^{2}$

Kegiatan penambangan rakyat telah memberikan dampak yang cukup besar bagi negara-negara berkembang dalam beberapa dekade terakhir. Penelitian di beberapa negara berkembang menunjukkan bahwa kegiatan penambangan rakyat telah memberi dampak positif di bidang ekonomi dengan tersedianya lapangan pekerjaan, sumber penghasilan bagi penduduk pedesaan dan meningkatkan pajak. ${ }^{3}$ Regulasi yang mengatur tentang pertambangan yaitu Undang-Undang Nomor 4 Tahun 2009 tentang Pertambangan Mineral dan Batu Bara (UU Minerba). Kegiatan usaha pertambangan rakyat pada gumuk merupakan jenis pertambangan mineral bukan logam dan pertambangan batuan, sebab kandungan yang ada di dalam gumuk tersebut seperti marmer, batu tulis, batu kapur, dolomit, kalsit, granit, basal, tanah liat dan pasir, juga tidak di pungkiri pertambangan gumuk juga mengandung jenis mineral logam seperti mengandung emas dan batu mulia. Selain dampak positif tersebut, ternyata penambangan rakyat juga memicu terjadinya masalah lingkungan yang erat kaitannya dengan degradasi lahan, khususnya di lokasi lubang tambang yang tidak direklamasi sehingga menyebabkan terjadinya erosi. ${ }^{4}$ Karena dirasa fungsi gumuk bukan hanya

l Suryadi. Fungsi Produksi Serta Penyusunan Neraca Ekonomi Dan Lingkungan Pada Sumber Daya Timah di Indonesia. Jurnal Teknologi Mineral dan Batubara. Volume 9 Nomor 3, 2013, hlm. 136.

2 Sulfiah A. Hariani.dkk. Peran Serta Masyarakat Dan Pemerintah Dalam Upaya Konservasi Gumuk Di Kabupaten Jember. Jurnal Saintifika Ilmu Pendidikan Mipa dan Mipa. Volume 17 Nomor 3, 2015, hlm. 47.

3 Ali R. Kurniawan Dan Wulandari Surono. Model ReklaMasi Tambang Rakyat Berwawasan Lingkungan : Tinjauan atas Reklamasi Lahan Bekas Tambang Batu Apung Ijobalit, Kabupaten Lombok Timur, Propinsi Nusa Tenggara Barat. Jurnal Teknologi Mineral dan Batubara Volume 9, Nomor 3, September 2013, hlm. 166.

4 Ibid, hlm. 166. 
sebagai penyeimbang lingkungan tapi sebagai pemuas kebutuhan masyarakat, selain kandungan mineral gumuk, terdapat kandungan tanah dan pasir yang mana fungsi dari kandungan gumuk tersebut sebagi dasar kebutuhan pembangunan kelangsungan hidup masyarakat banyak.

Kegiatan usaha pertambangan akan berpotensi mempengaruhi perubahan lingkungan hidup dalam skala besar maupun kecil tergantung pada teknis kegaiatannya. Untuk mengontrol dampak tersebut, pemerintah memberikan kewajiban kepada pelaku usaha pertambangan rakyat untuk melakukan reklamasi sebagaimana diatur dalam UU Minerba dan peraturan terkait lainnya. Namun, peraturan perundang-undangan belum bisa memberikan dampak yang positif dalam kelestarian dan perlindungan lingkungan hidup akibat dampak dari usaha pertambangan rakyat.

Berdasarkan Pasal 96 huruf (c) UU Minerba serta Pasal 2 ayat (1) Peraturan Pemerintah Nomor 78 Tahun 2010 tentang Reklamasi dan Pascatambang menjelaskna bahwa reklamasi lahan pascatambang merupakan kewajiban bagi pemegang Izin Usaha Pertambangan (IUP) dan Izin Usaha Pertambangan Khusus (IUPK). Sedangkan untuk pemegang Izin Usaha Pertambangan Rakyat (IPR) diatur lebih lanjut berdasarkan peraturan daerah kabupaten/kota dengan berpedoman pada Peraturan Pemerintah Nomor 78 Tahun 2010 tentang Reklamasi dan Pascatambang. Subtanto Joko Suprapto juga menjelaskan bahwa salah satu kegiatan pengakhiran tambang, yaitu reklamasi, yang merupakan upaya penataan kembali daerah bekas tambang agar menjadi daerah yang bermanfaat dan berdaya guna.

Hal ini bertujuan untuk meminimalisasi dampak kerusakan lingkungan hidup yang disebabkan oleh kegiatan usaha pertambangan yang telah dilakukan. UndangUndang Nomor 23 Tahun 2014 tentang Pemerintahan Daerah (UU Pemerintahan Daerah) menyebutkan bawha kewenangan sepenuhnya berada dalam kuasa gubernur dan pemerintahan pusat. Pasal 9 UU Minerba menjelsakan bahwa pemerintah daerah bupati/walikota berwenang dalam penerbitan IPR, maka rawan adanya perselisihan adanya tumpang tindih kewenangan mengenai izin usaha pertambangan. Artikel ini dibagi menjadi dua pengertian yang pertama adalah bagaimana bentuk tanggung jawab hukum pelaku usaha pertambangan rakyat untuk mereklamasi gumuk pasca kegiatan tambang dan pengertian yang kedua apa akibat hukum apabila tanggung jawab pelaku usaha pertambangan rakyat tidak melaksanakan reklamasi gumuk pascakegiatan tambang.

\section{BENTUK TANGGUNG JAWAB HUKUM PELAKU USAHA PERTAMBANGAN RAKYAT}

Kewajiban untuk mematuhi peraturan di bidang pertambangan merupakan akibat hukum yang harus diterima oleh setiap pelaku usaha pertambangan. Salah satu akibat hukum dari dilaksanakannya kegiatan tersebut oleh pelaku usaha pertambangan

\footnotetext{
5 Sutanto Joko Suprapto. Tinjauan Reklamasi Lahan Bekas Tambang dan Aspek Konservasi Bahan Galian. Buletin Sumber Daya Geologi. Volume 3 Nomor 1, 2008, hlm. 24.
} 
adalah melaksanakan kegiatan reklamasi lahan pascatambang sebagai bagian tidak terpisahkan dari kegiatan usaha pertambangan. Sifat wajib dari pelaksanaan kegiatan reklamasi lahan pascatambang ini menimbulkan tanggung jawab hukum yang wajib dipenuhi oleh pelaku usaha pertambangan. Dalam hal ini pelaku usaha pertambangan adalah pemegang IPR, kewajiban melaksanakan kegiatan reklamasi lahan pascatambang diatur dalam Peraturan Daerah Kabupaten/Kota dengan berpedoman pada Peraturan Pemerintah Nomor 78 Tahun 2010 tentang Reklamasi dan Pascatambang.

Menelaah pengertian "tanggung jawab" merujuk pada makna proses hukum bahwa seseorang dapat dituntut, diperkarakan dan dipersalahkan dan kesiapan menerima beban sebagai akibat dari sikap sendiri atau tindakan orang lain. Tanggung jawab sebagai keharusan sesorang untuk melaksanakan secara layak apa yang diwajibkan kepadannya. Konsep tanggung jawab hukum dalam bidang kegiatan usaha pertambangan diartikan sebagai liabillity. Dimana pengertian dari liabillity adalah kewajiban membayar ganti kerugian yang diderita. Tanggung jawab dalam konteks liability dapat juga diartikan sebagai menanggung segala suatu kerugian yang terjadi akibat perbuatannya atau perbuatan orang lain yang bertindak untuk dan atas namanya.

Dalam hal kegiatan usaha pertambangan yang dalam pelaksanaannya dilakukan oleh perusahaan jasa pertambangan, tanggung jawab atas segala bentuk akibat kegiatan pertambangan tetap berada pada pemegang IUP, IUPK maupun IPR berdasarkan ketentuan UU Minerba. Hal ini menyebabkan Spiro berusaha membuat definisi tentang pertanggungjawaban dengan meletakkan beberapa prasyarat timbulnya pertanggungjawaban diantaranya responsibillity as accountabillity (pertanggungjawaban sebagai akuntabilitas), responsibillity as couse (pertanggungjawaban sebagai sebab), responsibillity as abligation (pertanggungjawaban sebagai kewajiban). ${ }^{6}$ Dari sebab timbulnya pertanggungjawaban di atas, Spiro selanjutnya membagi ke dalam masingmasing dua arah pertangungjawaban antara lain explicit accountabillity dan implicit accountabillity. Explicit accountabillity merujuk kepada pertanggungjawaban keluar melalui pemeberian laporan atas segala tindakan dan akibat yang ditimbulkannya. Implicit accountabillity, Responbillity as accountabillity pada sisi lain cenderung dipahami sebagai pertanggungjawaban yang didasarkan pada tolak ukur tertentu untuk menilai tindakan pemerintah. $^{\top}$

Munculnya tanggung jawab pemegang IPR dalam hal kegiatan reklmasi lahan didasarkan atas kewajiban untuk melaksanakan kegiatan reklamasi lahan pascatambang sebagaimana diatur dalam Pasal 44 ayat (1) Peraturan Pemerintah Nomor 78 Tahun 2010 tentang Reklamasi dan Pascatambang Pemerintah di mana setiap kabupaten/kota sebelum menerbitkan IPR pada wilayah pertambangan rakyat, wajib menyusun rencana reklamasi dan rencana pascatambang untuk setiap wialayah

6 Herbert J Spiro. 1969. Responbillity in Goverment. Vsn Nosthand Reinhold Company: New York dalam Sutanto. Ibid, hlm. 14.

Ibid, hlm. 15. 
pertambangan rakyat. Pasal 44 ayat (2), maksud dari rencana reklamasi dan rencana pascatambang sebagimana dimaksud pada ayat (1) disusun berdasarkan dokumen lingkungan hidup yang telah disetujui oleh instansi yang berwenang sesuai dengan ketentuan peraturan perundang-undangan di bidang lingakungan hidup dan pengelolaan lingkungan hidup. Pasal 45 ayat (1) menjelaskan bahwa bupati/walikota menetapkan rencana reklamasi dan rencana pascatambang sebagaimna dimaksud dalam Pasal 44 untuk pemegang IPR. Pasal 45 ayat (2), menjelaskan bahwa pemegang IPR bersama dengan bupati/walikota wajib melaksanakan reklamasi dan pascatambang sesuai dengan rencana reklamasi dan rencana pascatambang sebagaimna diatur pada ayat (1). Sebagaimana Pasal 46, ketentuan lebih lanjut mengenai reklamasi dan pascatambang pada wilayah pertambangan rakyat diatur dengan perturan daerah kabupaten/kota dengan berpedoman pada Peraturan Pemerintah tersebut.

Pengaturan berdasarkan Peraturan Pemerintah Nomor 78 Tahun 2010 tentang Reklamasi dan Pascatambang masih belum efektif dan efisien mengenai aturan secara jelas terhadap kewajiban pelaku usaha pertambangan rakyat pemegang IPR. Faktanya peraturan daerah kabupaten/kota sendiri tidak banyak mengatur menganai reklamasi dan pascatambang tentang pelaku usaha pertambangan rakyat. Hanya beberapa daerah kabupaten/kota yang mengatur tentang reklamasi dan pascatambang bagi pemegang IPR. Kegiatan reklamasi lahan pascatambang yang diwajibkan bagi pelaku usaha pertambangan sebagaimana diatur dalam Undang-Undang Minerba serta peraturan terkait lainnya merupakan bagian yang tidak dapat dipisahkan dengan kegiatan usaha pertambangan. Di mana dalam pelaksanaannya, rencana kegiatan reklamasi lahan pascatambang yang telah disetujui merupakan parameter penentu tingkat keberhasilan kegiatan tersebut. Kegiatan reklamasi dianggap telah selesai apabila tingkat keberhasilan telah mencapai 100\% (seratus persen). Pada awalnya program reklamasi dan pasca tambang masih di laksanakan oleh Pemerintah Daerah dan masyarakat sekitar area pertambangan, perihal seperti ini sungguh memprihatinkan mengingat anggaran pemerintah tidak mampu mencukupi melakukan reklamasi akibat lahan bekas tambang. Oleh karenanya pemerintah meninjau ulang hal ini dan menetapkan kebijakan bahwa reklamasi dan pasca tambang wajib dilakukan oleh perusahaan pertambangan. ${ }^{8}$

Peraturan reklamasi dan pascatambang bagi pelaku usaha pertambangan rakyat pemegang IPR yang selanjutnya dalam pelaksanaannya dibuat oleh peraturan daerah kabupaten/kota yang tertuang dalam Peraturan Pemerintah Nomor 78 Tahun 2010 tentang Reklamasi dan Pascatambang maka hal ini pemerintah daerah kabupaten/kota harus jeli dalam memberikan izin atau mengeluarkan IPR kepada pelaku usaha pertambangan rakyat, karena di dalam pelaksanaan kegiatan reklamasi dan pasca tambang pemerintah daerah berpean aktif dalam penyusunan serta tanggung jawab reklamasi dan pascatambang bersama pemegang IPR. Pasal 1 angka 2 Undang-Undang

8 Ayu Linanda dan Hudali Mukti. Kewajiban Perusahaan Pertambangan Dalam Melaksanakan Reklamasi Dan Pascatambang Di Kota Samarinda. Jurnal Dosen Fakultas Hukum Universitas Widya Gama Mahakam Samarinda, hlm. 69. 
Nomor 32 Tahun 2009 Tentang Perlindungan dan Pengelolaan Lingkungan Hidup menyatakan, bahwa "Perlindungan dan pengelolaan lingkungan hidup adalah upaya sistematis dan terpadu yang dilakukan untuk melestarikan fungsi lingkungan hidup dan mencegah terjadinya pencemaran dan/atau kerusakan lingkungan hidup yang meliputi perencanaan, pemanfaatan, pengendalian, pemeliharaan, pengawasan, dan penegakan hukum".

Tanggung jawab perusahaan tambang terhadap lahan bekas tambang harus terencana sejak dibuatnya ketetapan IUP, IPR dan IUPK yang dibuat oleh perusahaan tambang. Perencanaan tersebut dimaksudkan agar perusahaan tambang dapat bertanggung jawab penuh terhadap lahan bekas tambang yang sudah tercemar dari hasil eksplorasi, baik pencemaran melalui air, tanah maupun udara. Pasal 53 ayat (1) Undang-Undang Nomor 32 Tahun 2009 Tentang Perlindungan dan Pengelolaan Lingkungan Hidup menyatakan, bahwa setiap orang yang melakukan pencemaran dan/atau perusakan lingkungan hidup wajib melakukan penanggulangan pencemaran dan/atau kerusakan lingkungan hidup. Setiap orang yang dimaksud dalam ketentuan Pasal 1 angka 32 Undang-Undang Nomor 32 Tahun 2009 Tentang Perlindungan dan Pengelolaan Lingkungan ialah orang perseorangan atau badan usaha, baik yang berbadan hukum maupun yang tidak berbadan hukum.

\section{A. Regulasi Berdasarkan Hukum Pertambangan}

UU Minerba mewajibkan adanya kegiatan reklamasi lahan pascatambang sebagai upaya konservasi lingkungan hidup dan menjaga fungsi lingkungan hidup secara berkelanjutan. Beberapa pengaturan tentang kegiatan reklamasi dan konservasi lingkungan hidup yang diatur dalam UU Minerba adalah sebagai berikut. Pertama, kewajiban pemegang IPR untuk menjaga keberlanjutan fungsi lingkungan hidup dalam melaksanakan kegiatan pertambangan merupakan upaya konservasi lingkungan hidup. Sebagaimana Pasal 70 menyatakan bahwa pemegang IPR wajib untuk melakukan kegiatan penambangan paling lambat tiga bulan setelah IPR diterbitkan, mematuhi peraturan perundang-undangan di bidang keselamatan dan kesehatan kerja pertambangan, pengelolaan lingkungan, dan memenuhi standar yang berlaku, mengelola lingkungan hidup bersama pemerintah daerah, membayar iuran tetap dan iuran produksi serta menyampaikan laporan pelaksanaan kegiatan usaha pertambangan rakyat secara berkala kepada pemberi IPR."

Kedua, pelaksanaan kegiatan usaha pertammbangan rakyat juga memperhatikan keberlangsungan fungsi lingkungan hidup dengan cara memperhatikan peraturan tentang perlindungan dan pengelolaan lingkungan hidup sebagaimana yang termuat dalam huruf b. Sedangkan lebih lanjut dalam huruf c dijelaskan bahwa upaya menjaga keberlajutan fungsi lingkungan hidup dilakukan bersama dengan pemerintah daerah, di mana salah satu bagian dalam pelaksanaannya dilakukan dengan cara melakukan kegiatan reklamasi lahan pasca tambang sebagaimana dijelaskan dalam penjelasan UU Minerba. Selain itu, dalam huruf e juga diwajibkan pemegang IPR untuk melaporkan kegiatan usaha pertambangannya secara berkala yaitu 4 bulan sekali, di mana kegiatan 
ini bertujuan untuk mempermudah pengawasan pelaksanaan kegiatan usaha pertambangan oleh pemerintah.

\section{B. Peraturan Menteri Energi dan Sumber Daya Mineral Nomor 18 Tahun 2008 tentang Reklamasi dan Penutupan Tambang}

Ketentuan mengenai reklamasi diatur dalam Peraturan Menteri Energi dan Sumber Daya Mineral Nomor 18 Tahun 2008 tentang Reklamasi dan Penutupan Tambang. Reklamasi adalah kegiatan yang bertujuan untuk memperbaiki atau menata kegunaan lahan yang terganggu sebagai akibat kegiatan usaha pertambangan agar dapat berfungsi dan berdayaguna sesuai dengan peruntukkannya. Beberapa hal yang harus diperhatikan sehubungan dengan pelaksanaan reklamasi adalah sebagai berikut. Reklamasi wajib dilakukan paling lambat satu bulan setelah tidak ada kegiatan usaha pertambangan pada lahan terganggu, yang meliputi lahan bekas tambang dan lahan di luar bekas tambang. Lahan di luar bekas tambang yang dimaksud meliputi timbunan tanah penutup, timbunan bahan baku/produksi, jalur transportasi, pabrik/instalasi pengolahan/pemurnian, kantor dan perumahan dan pelabuhan/dermaga. Pelaksanaan reklamasi tersebut dilaporkan oleh perusahaan pertambangan setiap tahun kepada menteri, gubernur, atau bupati/walikota sesuai dengan kewenangannya.

Dalam hal menteri, gubernur, atau bupati/walikota menilai bahwa perusahaan tidak memenuhi kriteria keberhasilan pelaksanaan reklamasi, baik berdasarkan evaluasi laporan dan atau berdasarkan penilaian lapangan, maka menteri, gubernur, atau bupati/walikota sesuai kewenangannya dapat menunjuk pihak ketiga untuk melaksanakan kegiatan reklamasi dengan menggunakan jaminan reklamasi. Sebagaimana diuraikan lebih lanjut bahwa reklamasi dilakukan oleh perusahaan pertambangan sesuai dengan rencana reklamasi, termasuk perubahan rencana reklamasi, yang telah disetujui oleh menteri, gubernur, atau bupati/walikota, sesuai dengan kewenangannya. Rencana Reklamasi disusun untuk pelaksanaan setiap lima tahun dengan rincian tahunan yang meliputi tata guna lahan sebelum dan sesudah ditambang, rencana pembukaan lahan, program reklamasi, dan rencana biaya reklamasi. Dalam hal umur pertambangan kurang dari lima tahun, maka rencana reklamasi disusun sesuai dengan umur tambang tersebut. Rencana reklamasi tersebut wajib disampaikan sebelum memulai kegiatan eksploitasi/operasi produksi.

Berdasarkan uraian tersebut dapat disimpulkan bahwa upaya pengembalian kondisi tanah agar dapat berfungsi sesuai dengan peruntukannya melalui reklamasi, bukan semata tanggung jawab perusahaan pertambangan, tapi juga tanggung jawab pemerintah. Dalam hal ini, menteri, gubernur, maupun bupati/walikota karena merekalah yang melakukan penilaian dan persetujuan rencana reklamasi, sekaligus melakukan pengawasan atas pelaksaan reklamasi oleh perusahaan-perusahaan pertambangan tersebut. Biaya reklamasi yang diperlukan untuk mengebalikan kondisi tanah harus ditanggung oleh perusahaan pertambangan. Biaya reklamasi, sebagai bagian dari biaya pengelolaan lingkungan hidup yang timbulselama tahap produksi, merupakan bagian dari beban produksi, yang merupakan salah satu faktor pengurang 
penjualan usaha (pendapatan yang berasal dari hasil tambang perusahaan) untuk memperoleh laba (rugi) kotor. Dalam rangka menjamin ketaatan perusahaan pertambangan untuk melakukan reklamasi sesuai dengan Rencana Reklamasi, perusahaan pertambangan wajib menyediakan Jaminan Reklamasi, yang besarnya sesuai dengan Rencana Biaya Reklamasi yang telah mendapatpersetujuan Menteri, Gubernur, maupun Bupati/Walikota sesuai kewenangannya.

Penetapan ketentuan mengenai kewajiban penyediaan jaminan reklamasi ini dapat pula memberikan kepercayaan kepada masyarakat dan instansi terkait dengan kemampuan perusahaan pertambangan dalam rangka melaksanakan rencana pengelolaan lingkungan, khususnya dalam melaksanakan reklamasi lahan bekas tambang. Pasal 24 ayat (1) Peraturan Menteri ESDM Nomor 18 Tahun 2008 menentukan bahwa jaminan reklamasi tersebut wajib ditempatkan oleh perusahaan sebelum perusahaan tersebut melakukan kegiatan eksploitasi/operasi produksi. Peraturan ini tidak mengatur jaminan reklamasi dalam kegiatan eksplorasi. Perlu dilakukan penelitian secara teknis, apakah pada tahap kegiatan eksplorasi tidak akan menimbulkan kerusakan lingkungan sehingga Pemerintah tidak mengatur mengenai jaminan reklamasi.

\section{Akibat Hukum Apabila Tanggung Jawab Pelaku Usaha Pertambangan Rakyat Tidak Dilaksanakan untuk Mereklamasi Gumuk Pasca Kegaiatan Tambang}

Akibat hukum adalah akibat suatu tindakan yang dilakukan untuk memperoleh suatu akibat yang dikehendaki oleh pelaku dan yang diatur oleh hukum. Tindakan yang dilakukannya merupakan tindakan hukum yakni tindakan yang dilakukan guna memperoleh sesuatu akibat yang dikehendaki hukum. ${ }^{9}$ Dalam hal ini pelaku usaha pertambangan rakyat dalam melakukan ataupun tidak melakukan suatu kewajiban sebagaimana mestinya maka sesuai dengan izin yang diberikan kepada pelaku usaha pertambangan rakyat, sanksi sebagai akibat hukum merupakan upaya dalam penegakan di bidang hukum pertambangan bagi pelaku usaha pertambangan dalam keiatan pertambangan yang dialakukannya.

Sanksi adalah bentuk hukuman atas suatu kesalahan yang dilakukan oleh pihak pembuat kesalahan. Black Law Dictionary dalam Samsul Ramli dan Fahrurrazi menjelaskan bahwa yang dimaksud sanksi adalah hukuman yang diterima akibat dari tidak mematuhi peraturan. ${ }^{10}$ Sehingga secara eksplisit diketahui bahwa sanksi merupakan salah satu bentuk akibat hukum, dimana pembuat kesalahan dipaksa untuk melakukan suatu hal tertentu karena telah melanggar peraturan. Dalam sistem hukum Indonesia dikenal beberapa bentuk sanksi. Pertama, sanksi pidana dalam hukum pidana yang berupa pidana pokok dan pidana tambahan sebagaimana dijelaskan dalam Pasal 10 Kitab Undang-Undang Hukum Pidana (KUHP). Kedua, kewajiban untuk memenuhi prestasi dan hilangnya suatu keadaan hukum yang diikuti adanya keadaan

\footnotetext{
9 Soeroso, R., SH. Pengantar Ilmu Hukum.Sinar Grafika. Jakarta. 200l, hlm. 295.

10 Samsul Ramli dan Fahrurrazi. Bacaan Wajib Swakelola Pengadaan Barang/Jasa. Jakarta: Visimedia Pustaka. 2014, hlm. 191.
} 
hukum baru dalam hukum perdata. Ketiga denda, penghentian sementara, pencabutan izin dan tindakan administratif lainnya dalam hukum administrasi.

Tanggung jawab pelaku usaha pertambangan rakyat untuk menyelesaikan pelaksanaan kegiatan reklamasi lahan pascatambang yang telah dilaksanakan bersama pemerintah sebagaimana yang dimaksud dalam Peraturan Pemerintah Nomor 78 Tahun 2010 Pelaksanaan Reklamasi Dan Pascatambang Pasal 44 ayat (1) dan Pasal 45 ayat (1), ayat (2) masih belum diatur lebih lanjut mengenai bentuk dan tatacara pelaksanaannya, yang pada akhirnya menimbulkan potensi tidak diselesaikannya kegiatan reklamasi lahan pascatambang oleh pelaku usaha pertambangan rakyat. Sehingga diperlukan pengaturan lebih lanjut sebagai upaya penyelesaian atas kerusakan lingkungan hidup pascatambang.

\section{Pelaksanaan Sanksi sebagai Akibat Hukum dalam Proses Penegakan Hukum Pertambangan bagi Pemegang IPR}

Penagakan hukum sesungguhnya merupakan upaya mendekatkan antara ide yang bersifat abstrak dengan kenyataanya. ${ }^{11}$ Kedalam hal yang bersifat abstrak itu dapat digolongkan tentang keadilan, kepastian hukum, dan kemanfaatan sosial. Keadilan, kepastian hukum, dan kemanfaatan sosial adalah unsur-unsur yang harus masuk dalam kerangka penegakan hukum. Suatu usaha untuk mewujudkan ide abstrak menjadi kenyataan. Proses untuk mewujudkan ide abstrak itulah merupakan inti dari penegakan hukum. ${ }^{12}$ Sedangkan inti dari prosesnya sendiri merupakan diskresi yang menyangkut perilaku pembuatan keputusan yang tidak secara ketat diatur oleh kaidah hukum, akan tetapi bertumpu pada unsur penilaian pribadi (rohani), untuk mewujudkan harmonisasi kehidupan secara proposional. ${ }^{13}$

Penegakan hukum biasa disebut oleh berbagai kalangan dalam bahasa inggris, yaitu law enforcement dan dalam bahasa belanda disebut rechtshandaving. Istilah penegakan banyak dipahami masyarakat umum selalu dialakukan dengan force, pendapat itu bermuara pada anggapan bahwa penegakan itu dalam konteks hukum pidana saja. Presepsi ini tidak dapat dipersalahkan, tetapi tidak dapat juga dibenarkan sepenuhnya, karena pada tataran realitas, penegakan hukum hanya bersandar pada teks formal hukum dalam bentuk peraturan perundang-undangan, diamana ketika teks diformalkan, maka teks akan terlihat oleh pakem-pakem dalam bahasa suatu sistem. ${ }^{14}$

Peneagakan hukum dalam konteks lebih luas, masih ada pejabat negara yang peran dan fungsinya sebagai penegak hukum, yaitu pejabat administrasi. ${ }^{15}$ Sejalan dengan itu, bahwa penegakan hukum adalah proses dilakukannya upaya tegaknya atau berfungsinya norma-norma hukum serta nyata sebagai pedoman perilaku dalam lalu

Il Satjipto Raharjo, Masalah Penegakan Hukum: Suatu Tinjuan Sosiologis. BPHN. Jakarta.tt, hlm. 15.

12 Nandang Sudrajat. Teiri dan Praktik Pertambangan Indonesia. Pustaka Yustisia. Yogyakarta, hlm 202.

13 T. Subarsyah Sumadikara. Penegakan Hukum Sebuah Pendakatan Politik Hukum dan Politik Kriminal. Kencana Utama. Bandung. Februari 2010, hlm. 41.

14 Anthon,Freddy Susanto.Semiotika Hukum:dari Dekontruksi Teks Menuju Progresivitas Makna. Refika Aditama. Bandung. 2005, hlm. 187.

15 A. Hamzah. Penegak Hukum Lingkungan. Arikha Media Cipta. Jakarta. 1995, hlm. 61. 
lintas atau hubungan-hubungan hukum dalam kehidupan bermasyarakat dan bernegara. ${ }^{16}$ Dalam konteks hukum pertambangan, apabila dilihat dari sudut subjek dan objeknya termasuk dalam pengertian hukum dalam arti luas. Karena didalamnya menyangkut berbagai segi penegakan hukum, yaitu hukum administrasi, hukum perdata, dan hukum pidana.

\section{E. Penegakan Hukum Administrasi}

Pelaksanaan penegakan hukum administrasi lebih bersifat preventif dalam rangka mendorong pelaku usaha pertambangan untuk menaati dan memenuhi seluruh ketentuan yang tercantum dalam izin yang dalam hal ini adalah IUP, IPR dan IUPK. Oleh karena itu, dalam konteks penegakan hukum administrasi sering pula dilakukan melalui pendektan-pendekatan negosiasi, persuasi, dam supervisi agar peraturan hukum atau syarat-syarat izin ditaati. ${ }^{17}$ Artinya, pihak pertama dan pihak utama dalam penegakan hukum administrasi adalah pejabat administrasi yang mengeluarkan izin. Secara teori hal itu dapat dipahami, karena pejabat administrasi negara yang mengeluarkan izin seyogyanya lebih mengetahui, apakah kegiatan itu memiliki izin atau tidak, atau apakah pemegang izin yang dikeluarkannya melanggar rambu-rambu yang tertuang dalam izin atau sebaliknya malah dilanggar.

Penegakan hukum adminstrasi sesuai fungsinya bersifat preventif, maka penerapan instrumen administrasi terutama dimaksudkan untuk pemulihan keadaan atau perbaikan kerusakan atau dengan kata lain ditunjukan kepada perbuatannya. ${ }^{18}$ Karena esensi penegakan hukum melalui instrumen hukum administratif bertujuan agar tindakan atau pengabaian yang sifatnya melanggar hukum atau tidak mematuhi persyaratan-persyaratan yang tertuang dalam izin. Dengan demikian, perbuatan tersebut harus segera diberhentikan dan segera mematuhi dengan cara melaksanakan persyaratan-persyaratan yang dimaksud. Artinya, simpul penegakan hukum administrasi adalah pada objek perbuatannya, dan wewenang untuk menekan penerima izin mematuhi ketentuan atau persyaratan yang tertuan dalam izin yang dimaksud adalah paksaan administratif.

Selain kewenangan paksaan, hukum administratif mengenal apa yang disebut sanksi administratif lainnya, yaitu penutupan perusahaan, uang paksaan, dan penarikan izin.Berkaitan dengan penerapan instrumen administratif dalam konteks penyelenggaraan pengolaan usaha pertambangan, pemerintah mempunyai kewenangan dalam hal pembinaan dan pengawasan, yang otoritasnya dilaksanakan oleh Menteri Energi dan Sumber Daya Mineral. Keenangan pemerintah dalam hal pembinaan diatur dalam Pasal 139 Undang-undang Minerba: 1. Pemberian pedoman standar pelaksanaan pengelolaan usaha pertambangan; 2. Pemberian bimbingan, supervisi, dan konsultasi; 3 . Pendidikan dan pelatihan; 4. Perencanaan, penelitian, pengembangan, pemantauan, dan

\footnotetext{
16 T. Subarsyah Sumadikara, supra note 13, hlm. 1-2.

17 A. Hamzah, supra note 15, hlm. 62.

18 T. Subarsyah Sumadikara, supra note 13, hlm. 104.
} 
evaluasi pelaksanaan penyelengaraan usaha pertambangan di bidang mineral dan batubara.

\section{F. Penegakan Hukum Perdata}

Proses hukum perdata secara nyata kurang diminati atau disenangi oleh masyarakat di negara kita, padahal secara yuridis, ruang penegakan hukum perdata adalah salah satu instrumen penegakan hukum yang mengatur bahwa khusus yang berkaitan dengan materi keperdataan secara formal harus melalui proses peradilan perdata disamping melalui abritase. ${ }^{19}$ Selain proses peradilan peradilan perdata yang memakan waktu, tenaga, biaya, hal yang harus disadari bahwa sengketa perdata dalam konteks pengusahaan pertambangan di negara kita yang marak terjadi saat ini adalah sengketa antara pemilik lahan dengan pelaku usaha pertambangan. Menyadari akan hal tersebut dalam konteks sengketa perdata, sebagaimana diuraikan di atas, terdapat dua kecenderungan. Pertama, di satu pihak, masyarakat setempat sebagai pemilik lahan cenderung menjadi korban. Kedua, pelaku usaha pertambangan cenderung lebih senang memakai jalur perdata karena dengan berbagai kekuatannya meskipun sengketa pengadilan berlangsung, pelaku usaha masih dapat melakukan kegiatan penambangannya dengan tenang.

Akomodasi gugatan perdata atas kegiatan usaha pertambangan yang merugikan masyarakat sesungguhnya memperolah ruang atau letimigasi hukum sebagaimana diatur dalam ketentuan Pasal 145 ayat (1) UU Minerba, yang menegaskan bahwa masyarakat yang terkena dampak neagtif langsung dari kegiatan usaha pertambangan berhak untuk memperoleh ganti rugi yang layak akibat kesalahan dalam pengusahaan kegiatan pertambangan sesuai dengan ketentuan peraturan perundang-undangan dan mengajukan gugatan kepada pengadilan terhadap kerugian akibat pengusahaan pertambangan yang menyalahi ketentuan. Tidak ada ketentuan lebih lanjut atau penjelasan lainnya tentang apa yang dimaksud akibat kesalahan dalam pengusahaan kegiatan pertambangan, kesalahan kesalahan-kesalah tersebut cenderung mngarah kepada aspek-aspek teknis, yaitu kesalahan yang disebabkan oleh human eror, kesalahan implementasi kerja, atau kealahan perencanaan, dimana akibat dari kesalahan tersebut menyebabkan kerugian bagi masyarakat setempat, masyarakat sekitar kegiiatan tambang dan/atau masyarakat yang berada dalam jangkauan kesalahan itu sendiri.

\section{G. Penegakan Hukum Pidana}

Ketentuan pidana dalam UU Minerba adalah instrumen terakhir yang diatur dalam undang-undang, merupakan ketentuan yang disesuaikan dengan perkembangannya dan tantangan dunia pertambangan setelah pergantian Undang-Undang Nomor 11 Tahun 2011 tentang Ketentuan-Ketentuan Pokok Pertambangan, konsekuensi dari adanya ketentuan pidana dalam UU Minerba maka hukum atau ketentuan itu harus ditegakkan. ${ }^{20}$ Ketentuan sanksi pidana dalam UU Minerba diatur dalam Pasal 158

19 Nandang Sudrajat, supra note 12, hlm. 208.

20 Ibid. hlm 212. 
sampai Pasal 165, yang memuat dua jenis sanksi pidana, yaitu sanksi hukuman penjara dan sanksi hukuman kurungan. Kedua jenis sanksi itu diikuti oleh sanksi denda, ketentuan sanksi pidana dimaksud sebagaimana Pasal 158 menyatakan bahwa setiap orang yang melakukan usaha pertambangan tanpa IUP, IPR, dan IUPK sebagaimana dimaksud dalam Pasal 37, Pasal 40 ayat (3), Pasal 48, Pasal 67 ayat (1), Pasal 74 ayat (1) atau ayat (5) dipidana dengan penjara paling lama 10 (sepuluh) tahun dan denda paling banyak Rp 10.000.000.000,00 (sepuluh miliar rupiah).

Selanjutnya, Pasal 159 UU Minerba menyatakan bahwa pemegang IUP, IPR atau IUPK yang dengan sengaja menyampaikan laporan sebagaimana dimaksu dalam Pasal 43 ayat (1), Pasal 70 huruf e, Pasal 81 ayat (1), Pasal 105 ayat (4), Pasal 110 atau Pasal 111 ayat (1) dengan tidak benar atau menyampaikan keterangan palsu dipidana dengan pidana penjara paling lama 10 (sepuluh) tahun dan denda paling banyak 10.000.000,00 (sepuluh miliar rupiah). Undang-undang Minerba Pasal 162, yang berbunyi: "Setiap orang yang merintangi atau meganggu kegiatan usaha pertambangan dari pemegang IUP atau IUPK yang telah memenuhi syarat sebagaimana dimaksud Pasal 136 ayat (2) dipidana dengan pidana kurungan paling lama 1 (satu) tahun atau denda paling banyak Rp 100.000.000,00 (seratus juta rupiah).”

Selanjutnya, sanksi pidana bagi badan hukum yang melakukan pelanggaran selain pidana yang dijatuhkan kepada pengurusnya juga diberlakukan terhadap badan hukumya itu sendiri. Sebagaimana diatur dalam Pasal 163, ada beberapa sanksi pidana tersebut. Pertama, berupa pidana denda dengan pemberatan ditambah 1/3 (satu per tiga) kali dari ketentuan maksimum pidana denda yang dijatuhkan. Kedua, pidana tambahan berupa pencabutan izin usaha dan/atau pencabutan status badan hukum. Sedangkan Pasal 164 UU Minerba, mengatur ketentuan terhadap pelaku tindak pidana yang melanggar ketentuan Pasal 158, Pasal 159, Pasal 160, Pasal 160, Pasal 161, dan Pasal 162, dapat dikenai pidana tambahan berupa perampasan barang yang tidak digunakan dalam melakukan tindak pidana, perampasan keuntungan yang diperoleh dari tindak pidana dan/atau kewajiban membayar biaya yang timbul akibat tindak pidana. Selanjutnya, Pasal 165 mengatur ketentuan tentang sanksi pidana yang berkenan dengan menyalahgunakan wewenang oleh pejabat administrasi negara, yang berbunyi: "Setiap orang yang mengeluarkan IUP, IPR, atau IUPK yang bertentangan dengan Undang-undang Minerba dan menyalahgunakan kewenanganya diberi sanksi pidana paling lama dua tahun penjara dan denda paling banyak Rp 200.000.000,00 (dua ratus juta rupiah)."

\section{KESIMPULAN}

Tanggung jawab pelaku usaha rakyat pertambangan dalam melakukan kegiatan reklamasi lahan pascatambang diawali dengan pembuatan, penilaian dan persetujuan rencana reklamasi lahan pascatambang sebagai kerangka pelaksanaan kegiatan reklamasi lahan pascatambang bersama pemerintah daerah. Seperti tertuang dalam Pasal 44 PP Nomor 7 tahun 2010 tentang Reklamasi dan Pascatambang, hanya saja 
masih terjadi kekosongan norma mengenai bentuk dan tatacara pelaksanaan tanggung jawab pelaku usaha pertambangan rakyat ketika tidak adanya dana jaminan reklamasi lahan pascatambang. Sehingga secara tidak langsung peraturan ini memberikan peluang kepada pelaku usaha pertambangan rakyat untuk tidak menyelesaikan kegiatan reklamasi lahan pascatambang dan turut berperan serta dalam kegiatan pemanfatan lahan pascatambang yang tidak produktif.;

Penerapan sanksi kepada pelaku usaha pertambangan rakyat sebagai salah satu bentuk akibat hukum atas tidak dilaksanakannya suatu kewajiban merupakan upaya represif atas suatu permasalahan, karena sanksi merupakan salah satu akibat hukum yang bersifat memaksa ketika tidak dilaksanakannya suatu kewajiban yang telah diamanatkan oleh suatu peraturan. Dalam kaitannya dengan pelaksanaan kegiatan reklamasi lahan pascatambang sebagai bagian dari proses pemanfaatan sumber daya alam, sanksi yang dapat diterapkan adalah pemberian kewajiban untuk membayar denda kepada pelaku usaha pertambangan rakyat apabila kegiatan reklamasi lahan pascatambang tidak dilaksanakan sebagaimana yang telah direncanakan. Pemberian kewajiban untuk membayar denda kepada pelaku usaha tersebut rakyat tidak menghilangkan kewajiban pelaku usaha pertambangan rakyat beserta pemerintah daerah untuk memulihkan kerusakan lingkungan pascatambang dengan cara menyediakan kekurangan dana yang dibutuhkan oleh pihak ketiga. Hal ini bertujuan untuk memberikan efek jera kepada pelaku usaha pertambangan rakyat yang lain agar pembiaran atas kerusakan lingkungan hidup pascatambang tidak terjadi lagi.

Hendaknya pemerintah, khusunya Menteri Energi Sumber Daya Mineral membuat pengaturan lebih lanjut mengenai kewajiban tentang dana jaminan kepada pelaku usaha pertambangan rakyat, atau melakukan perubahan atas Peraturan Menteri Energi Dan Sumber Daya Mineral Nomor 7 Tahun 2014 tentang Pelaksanaan Reklamasi dan Pascatambang Dalam Kegiatan Usaha Pertambangan. Di mana perubahan atas Peraturan Menteri yang dimaksud terdapat penambahan pasal yang menjelaskan tentang adanya suatu norma yang mewajibkan bagi pemerintah daerah membuat regulasi tetang reklamsi dan pascatambang bagi pelaku usaha pertambangan rakyat yang didalamnya memuat mengenai dana jaminan bagi pelaku usaha pertambangan rakyat untuk kegiatan reklamasi dan pascatambang secara jelas.

\section{DAFTAR PUSTAKA}

A. Hamzah. 1995. Penegak Hukum Lingkungan. Jakarta. Arikha Media Cipta.

Ali R. Kurniawan dan Wulandari Surono. 2013. Model Reklamasi Tambang Rakyat Berwawasan Lingkungan: Tinjauan Atasa Reklamasi Lahan Bekas Tambang Batu Apung Ijobalit, Kabupaten Lombok Timur, Propinsi Nusa Tenggara Barat. Jurnal Teknologi Mineral dan Batubara. (Volume 9 Nomor 3).

Anthon,Freddy Susanto. 2005. Semiotika Hukum:dari Dekontruksi Teks Menuju Progresivitas Makna. Bandung. Refika Aditama. 
Ayu Linanda dan Hudali Mukti. Kewajiban Perusahaan Pertambangan Dalam Melaksanakan Reklamasi Dan Pascatambang Di Kota Samarinda. Jurnal Dosen Fakultas Hukum Universitas Widya Gama Mahakam Samarinda.

Herbert J Spiro. 1969. Responbillity in Goverment. New York. Vsn Nosthand Reinhold Company.

Nandang Sudrajat. 2013. Teori dan Praktik Pertambangan Indonesia. Yogyakarta. Pustaka Yustisia.

R. Soeroso, 2001. Pengantar Ilmu Hukum. Jakarta. Sinar Grafika.

Samsul Ramli dan Fahrurrazi. 2014. Bacaan Wajib Swakelola Pengadaan Barang/Jasa. Jakarta: Visimedia Pustaka.

Satjipto Raharjo, Masalah Penegakan Hukum: Suatu Tinjuan Sosiologis. Jakarta. BPHN. tt.

Subtanto Joko Suprapto. 2008. Tinjauan Reklamasi Lahan Bekas Tambang Dan Aspek Konservasi Bahan Galian. Buletin Sumber Daya Geologi. (Volume 3 Nomor 1).

Sulfiah A. Hariani.dkk. 2015. Peran Serta Masyarakat Dan Pemerintah Dalam Upaya Konservasi Gumuk Di Kabupaten Jember. Jurnal Saintifika Ilmu Pendidikan Mipa dan Mipa. (Volume 17 Nomor 3).

Suryadi. 2013. Fungsi Produksi Serta Penyusunan Neraca Ekonomi Dan Lingkungan Pada Sumber Daya Timah di Indonesia. Jurnal Teknologi Mineral dan Batubara. (Volume 9 Nomor 3).

T. Subarsyah Sumadikara. Februari 2010. Penegakan Hukum Sebuah Pendakatan Politik Hukum dan Politik Kriminal. Bandung. Kencana Utama. 